Journal of Management

Vol. XX No. X, Month XXXX 1-29

DOI: $10.1177 / 0149206318811567$

(C) The Author(s) 2018

(c) (1) (8)

Article reuse guidelines:

sagepub.com/journals-permissions

\title{
The Dark Side of Visionary Leadership in Strategy Implementation: Strategic Alignment, Strategic Consensus, and Commitment
}

\author{
Nüfer Yasin Ateş \\ Bilkent University \\ Tilburg University \\ Murat Tarakci \\ Erasmus University Rotterdam \\ Jeanine Pieternel Porck \\ Oklahoma State University \\ Daan van Knippenberg \\ Drexel University \\ Patrick J. F. Groenen \\ Erasmus University Rotterdam
}

\begin{abstract}
Drawing from visionary leadership and strategy process research, we theorize and test the mechanism through which middle and lower-level managers' visionary leadership affects their teams' strategic commitment. The management literature extols the virtues of visionary leadership. In contrast to this positive stance, we reveal a dark side to visionary leadership. Our theoretical framework suggests that team manager visionary leadership harms team strategic consensus when the manager is not strategically aligned with the CEO, which in turn diminishes team commitment to the strategy. In contrast, when a team manager is strategically aligned with the CEO, team manager visionary leadership is positively related to team strategic consensus and subsequently to team strategic commitment. Data from 136 teams from two organizations support our moderated mediation model. A supplemental analysis of the content of strategic consensus and additional qualitative interviews with managers and employees in one of these organizations provide additional insights concerning the meaning of the theorized relations in practice.
\end{abstract}

Keywords: visionary leadership; strategic consensus; strategic commitment; strategic alignment; behavioral strategy; strategy process

Acknowledgments: We thank Tomi Laamanen and Steven Floyd for their invaluable feedback on the earlier versions of this manuscript. We are also grateful to the editor and three anonymous reviewers for their constructive comments. Corresponding author: Nüfer Yasin Ateş, Bilkent Üniversitesi, Ankara, 06800, Turkey.

E-mail: n.y.ates@bilkent.edu.tr 
Any strategy, no matter how well formulated, is ineffective without people throughout the organization putting the strategy into practice (Burgelman, 1991; Lee \& Puranam, 2016; Noble, 1999). Failure to implement strategy is often due to teams at the middle and lower levels of the organization lacking commitment to the strategy (Balogun \& Johnson, 2005; Kotter, 1995; Labianca, Gray, \& Brass, 2000). Critical to the development of such strategic commitment (willingness to exert effort for the strategy; Dooley, Fryxell, \& Judge, 2000; Wooldridge \& Floyd, 1990) is the leadership of team managers (Balogun, 2003; Huy, 2002). These middle and lower-level managers are responsible for communicating and clarifying the strategy (Floyd \& Wooldridge, 1992; Wooldridge, Schmid, \& Floyd, 2008). As such, these team managers' visionary leadership - the communication of an image of a future for the team and organization to persuade employees to contribute to the realization of that vision (Griffin, Parker, \& Mason, 2010; Stam, Lord, van Knippenberg, \& Wisse, 2014; Westley \& Mintzberg, 1989) - plays a key role. Visionary leadership directly speaks to the creation of strategic commitment because it is focused on motivating the pursuit of a strategic vision (Carton, Murphy, \& Clark, 2014; Yukl, 2012).

Both the leadership literature (Carton et al., 2014; Greer, Homan, De Hoogh, \& Den Hartog, 2012; Griffin et al., 2010; Stam et al., 2014; Venus, Stam, \& van Knippenberg, 2013, 2018) and strategy process literature (Baum, Locke, \& Kirkpatrick, 1998; Elenkov, Judge, \& Wright, 2005; Westley \& Mintzberg, 1989) extol the virtues of visionary leadership. In support of this positive view, research on visionary leadership has so far reported only on organizational and contextual variables that increase the positive effects of visionary leadership (for a review, see van Knippenberg \& Stam, 2014). Yet, despite the recognition of the relevance of visionary leadership for the strategy process, only a handful of strategy studies examined visionary leadership, and these focused exclusively on top managers (Baum et al., 1998; Elenkov et al., 2005; Westley \& Mintzberg, 1989). It is an important omission for strategy process research that no study focused on visionary leadership of managers beyond the $\mathrm{C}$-suite, because the leadership of these middle managers bridges $\mathrm{C}$-level strategy formulation and team-level strategy implementation. The current view seems to be that findings on CEO visionary leadership generalize to team managers beyond the $\mathrm{C}$-suite, in that visionary leadership is considered a desirable skill for managers at all hierarchical levels (Goleman, 2000; Ibarra \& Obodaru, 2009). However, such a generalization may not be warranted. The general positive stance toward visionary leadership when applied to team managers does not align with findings in the strategy literature that these managers often have different views of strategy than top managers and frequently engage in counterproductive efforts or sabotaging of strategy implementation (Burgelman, 1991; Guth \& MacMillan, 1986; Meyer, 2006; Wooldridge \& Floyd, 1990). Therefore, it is not a given that middle managers would employ their visionary leadership to pursue the implementation of top management strategy, and it is thus not a given that their visionary leadership has a positive influence.

We challenge the unconditional positive perspective on visionary leadership, developing a model of the mechanism through which team manager visionary leadership affects team strategic commitment. This is an issue at the team level of analysis (team manager leadership as an influence on team strategic commitment), and we propose that team manager visionary leadership is negatively related to team strategic commitment when the team manager is not strategically aligned with the CEO (i.e., does not have a similar understanding of the strategy), because this constellation results in the team receiving mixed messages about the 
strategy from the manager and the CEO. The consequence is lower team strategic consensus (i.e., shared understanding of the organizational strategy; Kellermanns, Walter, Lechner, \& Floyd, 2005), with lower team strategic commitment as a result. Thus, we propose that team manager visionary leadership is a positive influence on team strategic consensus and team strategic commitment only to the extent that the team manager is strategically aligned with the CEO. We present analyses based on data collected from 136 middle- and lower-level teams in two organizations in support of this proposition.

Our study contributes to the visionary leadership and strategic management literatures. We challenge the view of visionary leadership as a purely positive phenomenon (Baum et al., 1998; Kirkpatrick, Wofford, \& Baum, 2002; van Knippenberg \& Stam, 2014) and show that there is a dark side to visionary leadership. This is an important insight for research on visionary leadership and on strategy implementation, because it provides an important qualification of the notion that visionary leadership builds strategic commitment. Our research shows that this is the case only to the extent that the team manager and CEO are strategically aligned; absent this precondition, team manager visionary leadership is a negative influence. By theoretically and empirically mapping how team manager visionary leadership affects team strategic commitment, we also integrate visionary leadership and strategy process research. Doing so, we answer calls to strengthen the psychological grounding and practical usefulness of strategy theory, along the lines of behavioral strategy (Hutzschenreuter \& Kleindienst, 2006; Powell, Lovallo, \& Fox, 2011). Moreover, by focusing on team manager visionary leadership, we add to the literature on the strategic roles of managers outside the C-suite (Floyd \& Lane, 2000; Floyd \& Wooldridge, 1992).

\section{Theoretical Background}

Strategy implementation requires commitment from teams throughout the organization (Noble, 1999). Strategic commitment is defined as the shared voluntary effort, cooperation, and support for the strategy within an organizational unit (Dess, 1987; Dooley et al., 2000; Wooldridge \& Floyd, 1990). When employees are committed to the strategy, they recognize that their efforts are an integral part of the organization's successful strategy implementation. They engage in extrarole behavior, work with others cooperatively, and are less inclined toward behavior that serves only their self-interests (Leana \& Van Buren, 1999). Strategic commitment thus goes beyond a positive attitude toward the strategy; it includes employee willingness to exert effort in implementing the strategy (Herold, Fedor, Caldwell, \& Liu, 2008; Korsgaard, Schweiger, \& Sapienza, 1995).

Ensuring teams' strategic commitment during strategy implementation is a challenge (Balogun \& Johnson, 2005; Beer \& Eisenstat, 2000; Hailey \& Balogun, 2002; Labianca etal., 2000). Scholars have, for instance, reported on employee resistance (Labianca et al., 2000) and complacency (Hailey \& Balogun, 2002) toward organizations' strategic change efforts. Thus, an important question for strategy research is how organizations can build strategic commitment in their teams during strategy implementation.

The answer lies with middle and lower-level managers. These managers are critical in resolving resistance or complacency in their teams and in ensuring team strategic commitment. They are the ones who must interpret the strategy in the context of daily operations, identify the actions required to implement the strategy, and communicate and clarify the 
underlying logic of the strategy to their subordinates (Floyd \& Wooldridge, 1992; Wooldridge etal., 2008). Strategy process research hence recognizes that strategy implementation requires leadership throughout the organization (Balogun \& Johnson, 2005; Floyd \& Wooldridge, 1999; O’Reilly, Caldwell, Chatman, Lapiz, \& Self, 2010; Wooldridge etal., 2008). There thus is a strong case to focus on leadership in strategy process research.

Yet, despite the calls to examine the role of leadership in implementing organizational strategies (Boal \& Hooijberg, 2001; Cannella \& Monroe, 1997), only a few studies have done so, almost exclusively focusing on leadership at the upper echelons (Baum et al., 1998; Elenkov et al., 2005; Larwood, Falbe, Kriger, \& Miesing, 1995; Westley \& Mintzberg, 1989). Leadership has a stronger presence in the behavioral research tradition, but that research stream overlooks the role of leadership in the strategy process. Without understanding the role of the leadership of middle and lower-level managers in strategy implementation, however, we face a serious lacuna in our comprehension of the impact of leadership on strategy implementation (Balogun, 2003; Hutzschenreuter \& Kleindienst, 2006; Huy, 2002; Wooldridge et al., 2008).

To this aim, we focus on visionary leadership: leader communication of an image of the future for the team and organization to persuade others to contribute to the realization of that future (Hunt, 1991; Sashkin, 1988; Stam et al., 2014; van Knippenberg \& Stam, 2014). Core to leadership is its role in mobilizing and motivating followers for collective objectives (Yukl, 2012), and nowhere is this more explicit than in the notion of visionary leadership (Carton et al., 2014; Larwood et al., 1995). Visionary leadership is central to effective leadership in the strategy implementation context because, as it is understood from a strategy process perspective, it entails the communication of a strategic vision with the intention of persuading employees to contribute to the realization of that vision. Visionary leadership is highly relevant to the strategy process (Westley \& Mintzberg, 1989), because organizational strategy is the embodiment of an organization's desired future state and its path to realize that vision, and visionary leadership is intended to motivate and mobilize followers toward achieving that future state (Carton et al., 2014; Larwood et al., 1995). The communication and persuasion elements of visionary leadership also closely align visionary leadership with strategic commitment, because building commitment to the strategy requires the communication of the strategy such that employees are persuaded to exert effort to implement the strategy.

\section{A Moderated Mediation Model of Visionary Leadership and Strategic Commitment}

The literature views vision communication as a highly positive leadership behavior (for a review, see van Knippenberg \& Stam, 2014). Visionary leadership mobilizes support for a collective cause (Shipley \& Michela, 2006), creates shared perceptions of followers' role in vision pursuit, and motivates to pursue the vision (Stam etal., 2014). In strategy research, CEO visionary leadership has been related to organizational growth and innovativeness (Baum et al., 1998; Elenkov etal., 2005) and is regarded as positive on many accounts (Baum etal., 1998; Elenkov etal., 2005; Westley \& Mintzberg, 1989). Generalizing these positive findings to the strategy implementation context would suggest that visionary leadership of managers outside of the $\mathrm{C}$-suite should also ensure team strategic commitment. 
Figure 1

The Research Model

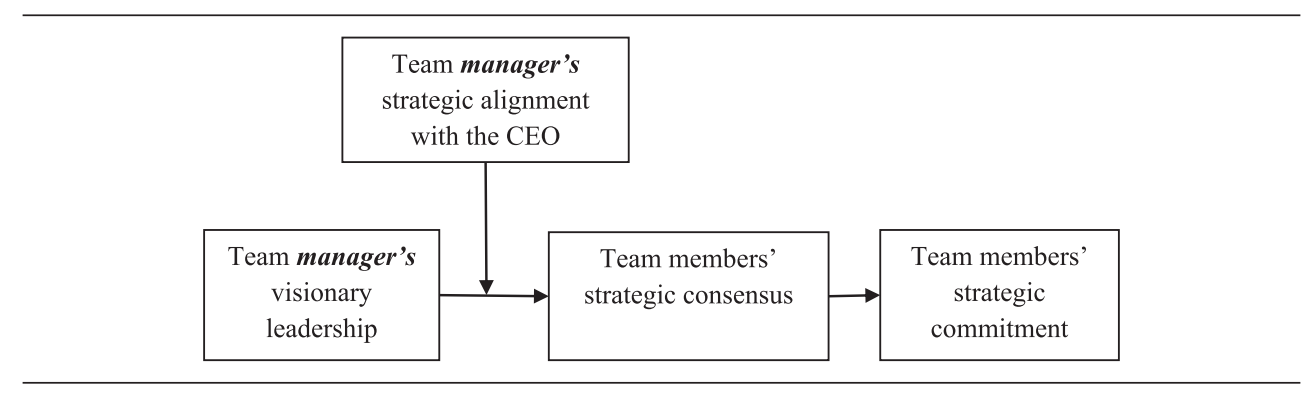

This intuitive generalization, however, may not be warranted. Because the CEO has the decision authority for company strategy, CEO visionary leadership can be assumed to be aligned with the company's strategy. This assumption is not warranted for middle and lowerlevel managers, since these managers do not have decision authority about company strategy, and it is not uncommon for team managers to disagree with company strategy. The strategy process literature has highlighted that team managers often have different views of strategy than top managers (Burgelman, 1991; Walsh, 1995; Wooldridge \& Floyd, 1990). Some studies even report that these divergent views lead to efforts of managers that derail strategy implementation (Balogun \& Johnson, 2005; Guth \& MacMillan, 1986; Hailey \& Balogun, 2002; Meyer, 2006). Thus, we cannot assume that team manager visionary leadership will commit the team to the organizational strategy without taking into consideration the extent to which team managers are aligned with top management (the CEO) in their understanding of the organization's strategy.

As we outline in the following sections and as shown in Figure 1, we propose a moderated mediation model (Edwards \& Lambert, 2007; Muller, Judd, \& Yzerbyt, 2005; Preacher, Rucker, \& Hayes, 2007), in which the influence of team manager visionary leadership on strategic commitment as mediated by strategic consensus depends on the moderating influence of team manager strategic alignment with the CEO. We develop theory indicating that team manager visionary leadership either fosters team strategic commitment by cultivating team strategic consensus or hampers team strategic commitment by reducing team strategic consensus, contingent on the team manager's level of strategic alignment with the CEO.

\section{The Mediating Role of Strategic Consensus}

Before a team can commit to the strategy, team members need to know and understand the strategic vision. As such, we argue that research on strategic consensus, the shared understanding of the organization's strategy (Kellermanns et al., 2005), forms an important starting point in developing an understanding of how team manager visionary leadership may influence team strategic commitment. A rich research tradition in strategic management supports the central role of strategic consensus in strategy implementation (Kellermanns et al., 2005; Kellermanns, Walter, Floyd, Lechner, \& Shaw, 2011). This is because strategic consensus reduces the pursuit of subunit goals over organizational goals (Ketokivi \& Castaner, 2004) 
and facilitates communication, cooperation, and coordination focused on realizing the strategy (Bourgeois, 1980; Cannon-Bowers, Salas, \& Converse, 2001; Kellermanns et al., 2005).

Some strategic consensus studies that looked at top management teams considered strategic consensus and strategic commitment as two dimensions of strategic consensus (Amason, 1996; Dess \& Origer, 1987; Wooldridge \& Floyd, 1989). Those studies on top management teams converged on the idea that as these top-level decision makers developed agreement on the importance of certain strategic priorities, they also developed a commitment to the realization of their own decisions. However, as the strategy process field progressed to focus on other actors beyond top managers, strategy research abandoned this approach and considered consensus and commitment as distinct constructs. In their review of strategic consensus, Kellermanns etal. (2005: 723), for instance, explicitly did not incorporate "the concept [commitment] in... [their] definition [of strategic consensus], nor are... [they] proposing it as a necessary component of strategic consensus." This is in line with the small-teams literature, which conceptually and empirically distinguishes shared understanding and commitment (Carson, Tesluk, \& Marrone, 2007; Mathieu, Maynard, Rapp, \& Gilson, 2008). Thus, recent work on strategic consensus operationalizes consensus as the shared understanding of strategy, without adding commitment as part of the construct definition (González-Benito, Aguinis, Boyd, \& Suárez-González, 2012; Tarakci, Ates, Porck, van Knippenberg, Groenen, \& de Haas, 2014; Walter, Kellermanns, Floyd, Veiga, \& Matherne, 2013).

Strategic consensus as a positive influence on strategic commitment has so far been established only for top management teams (Dess \& Priem, 1995; Dooley et al., 2000) but should apply to teams throughout the organization. Research provides evidence that team members who have a common sense of purpose and agreed-upon goals are more likely to feel motivated, empowered, and committed to their team and work (Kirkman \& Rosen, 1999; Martocchio \& Frink, 1994; Mathieu etal., 2008, Mathieu, Heffner, Goodwin, Salas, \& Cannon-Bowers, 2000). As such, we propose that a similar influence holds for team strategic consensus and strategic commitment. Shared understanding, and thus social validation (van Knippenberg, van Ginkel, \& Homan, 2013), among team members gives them confidence in the strategy; strategic consensus leads to strategic commitment by influencing both the perceived desirability and feasibility of the strategy. Moreover, strategic consensus is a positive influence on strategic commitment because it may reduce the uncertainty associated with strategic change. Uncertainty about (strategic) change processes and the associated loss of control and fear of failure may invite negative responses to strategic change (Coch \& French, 1948; Fedor, Caldwell, \& Herold, 2006; Oreg, 2003). Conversely, reducing uncertainty is associated with greater support for change (Sharma \& Good, 2013). By reducing uncertainty and increasing the perceived feasibility and desirability of strategic objectives, strategic consensus can thus build strategic commitment. Accordingly, for teams throughout the organization beyond the $\mathrm{C}$-suite, we pose the following:

Hypothesis 1: Strategic consensus among team members is positively related to team strategic commitment.

At first blush, it seems straightforward that team manager visionary leadership is a positive influence in shaping both team strategic consensus and strategic commitment. By communicating the desirability of the envisioned future outcomes of the strategy and by outlining how these outcomes can be realized through collaborative efforts of the team (Carton etal., 2014; Stam 
etal., 2014; Stam, van Knippenberg, \& Wisse, 2010), visionary leadership can create a shared understanding of the strategy in a team and thus team strategic commitment. This holds all the more because in consensus formation, managers not only pass on their understanding of the strategy to their subordinates but also confront their subordinates' concerns and issues about the strategy. When issues raised are resolved effectively, team members develop higher levels of commitment to the strategy (Dooley etal., 2000). Because team managers are physically and personally closer to their team members than the CEO, they are better able to motivate their team toward the realization of the organization's strategic vision. Therefore, it seems straightforward to hypothesize that strategic consensus among team members mediates the relationship between team manager visionary leadership and team strategic commitment.

However, such a hypothesis assumes that team managers always use their visionary leadership to cultivate consensus in their teams about the strategy as formulated by top management, while this is unlikely given that team managers often have different views of strategy than top managers (Burgelman, 1991; Walsh, 1995; Wooldridge \& Floyd, 1990). That is, the proximity between a team manager and his or her team members also creates an opportunity for team manager visionary leadership to influence team member strategic understanding along his or her own opinion of the strategy rather than the strategy as formulated by the CEO and other top managers. Thus, the seemingly straightforward relationship of team managers' visionary leadership and team strategic commitment, mediated by strategic consensus, may not always hold due to possible strategic misalignment between the manager and CEO.

\section{The Moderating Role of Team Manager Strategic Alignment With the CEO}

Middle and lower-level managers are not just passive links passing on orders from upper echelons to subordinates (Balogun \& Johnson, 2004; Rouleau \& Balogun, 2011). Part of team managers' role is to help their team make sense of what the strategy entails and how it impacts their domain (Balogun, 2003; Balogun \& Johnson, 2005; Huy, 2011). Here, team managers have substantial discretion in what they envision and communicate. Researchers reported on cases where managers instructed their teams to carry on as usual (Currie \& Procter, 2005) or even to counteract strategic changes imposed by the organization (Balogun \& Johnson, 2004). Even when top management communications and actions may impose boundaries on what managers can communicate in terms of what the strategy is, managers maintain leeway in communicating what they believe the strategy should be. That is, middle and lower-level managers may engage in visionary leadership to create a shared understanding of the strategy as envisioned by top management, but they may also rely on visionary leadership to persuade their team about what is or would be a desirable strategy that deviates from the views of top management.

This is no hypothetical consideration; team managers may have different understandings of the strategy than top management based on daily operations that may be more salient to them than strategic considerations (Walsh, 1995) or because they are more focused on their own (personal or team) interests than on the interests of the organization (Guth \& MacMillan, 1986; Meyer, 2006). Their strategic views may also differ from top management because their interaction with top management varies (Balogun \& Johnson, 2004, 2005), they hold different boundary-spanning positions (Floyd \& Wooldridge, 1997), or top management's ambivalence about strategy provides middle management with broad scope for interpretation of strategic initiatives (Sillince \& Mueller, 2007). 
We propose that the effectiveness of team manager visionary leadership in creating team strategic consensus depends on the extent to which the manager is strategically aligned with the CEO (i.e., CEO strategic understanding should reflect top management strategic understanding; Hambrick \& Mason, 1984). In line with other studies, we define team manager strategic alignment as the similarity of perceptions of the importance of strategic priorities between an individual team manager and the CEO (Balogun \& Johnson, 2004; Colbert, Kristof-Brown, Bradley, \& Barrick, 2008; Raes, Heijltjes, Glunk, \& Roe, 2011). ${ }^{1}$ We argue that only when a manager is strategically aligned with the CEO will he or she act as a facilitator of the strategy and create strategic consensus within his or her team. When a manager is strategically aligned with the CEO, his or her visionary leadership will align with strategic messages from top management (i.e., aligned visionary leadership).

In the absence of team manager strategic alignment, however, team manager visionary leadership (i.e., misaligned visionary leadership) may undermine strategic consensus. When team manager visionary leadership does not revolve around the strategic priorities advocated by top management but around other (idiosyncratic) strategic priorities, the manager in effect attempts to build consensus on a strategy different from the strategy as defined by top management. Such misaligned visionary leadership is likely to invite resistance to top management's strategic vision and may give rise to initiatives that are not in line with the strategy, slowing down or even sabotaging strategy implementation (Guth \& MacMillan, 1986; Floyd \& Wooldridge, 1997). Such misalignment created by visionary leadership creates a "presence of competing and conflicting voices" (Clegg, Courpasson, \& Phillips, 2006: 150). The team will be exposed to contradicting messages about the strategy from their manager versus from top management. This contradiction undermines the effectiveness of both messages, as the team is left confused about the strategy or divides along lines where some are more persuaded by the one understanding of the strategy and others more by the other understanding. Consequently, team strategic consensus is lower the more team manager visionary leadership is informed by an understanding of the strategy that is misaligned with the CEO's understanding. Hence, we hypothesize the following:

Hypothesis 2: The relationship between team manager visionary leadership and team strategic consensus is moderated by team manager strategic alignment with the CEO such that the relationship changes from negative to positive as the strategic alignment between the manager and CEO increases.

Following the distinction between aligned visionary leadership and misaligned visionary leadership, we propose that the indirect effect of team manager visionary leadership on strategic commitment, through strategic consensus, is moderated by team manager strategic alignment. As visionary leadership can either foster or harm strategic consensus contingent on team manager strategic alignment (Hypothesis 2), we expect the indirect effect of visionary leadership on strategic commitment to be conditional on team manager strategic alignment, too. This proposition qualifies as moderated mediation because "the mediating process that is responsible for producing the effect of the treatment variable on the outcome depends on the values of the moderator" (Muller etal., 2005: 854; see also Edwards \& Lambert, 2007; Preacher etal., 2007). We pose that when team manager strategic alignment is high, visionary leadership creates higher commitment to strategy through enhanced team strategic consensus; when team manager strategic alignment is low, visionary leadership has a negative effect on 
team strategic commitment through diminished team strategic consensus. Accordingly, we hypothesize a first-stage moderated-mediation as follows:

Hypothesis 3: The indirect effect of team manager visionary leadership on team strategic commitment through strategic consensus is moderated by team manager strategic alignment.

\section{Method}

\section{Organizational Context}

To test our hypotheses, we collected data from two organizations. ${ }^{2}$ Both organizations are large service organizations operating in western Europe. The first organization maintains a national infrastructure network that provides households with energy. The second organization governs the maintenance and extensions of a national transportation network. The two organizations have similar strategy processes and operate in comparable relatively stable environments, which is a context in which strategic consensus and commitment are shown to facilitate strategy implementation (Kellermanns et al., 2011; Priem, 1990). Because strategic commitment is beneficial to strategy implementation in these organizations, they offer a proper context to test the moderating effect of manager-CEO alignment.

The organizations also provided a good setting for our research because both had intended strategies determined by their top management team (TMT; Mintzberg and Waters, 1985). These strategies were developed in response to changes in regulations and the environment of the company. These changes made it crucial to strive for implementation of the strategies with minimal distortion. This assures the presence of strong strategic direction, which can conflict with individual managers' idiosyncratic strategic views. In both organizations, the TMT had worked on top-down strategy implementation for over a year before the start of our study.

The TMTs in both organizations recognized the need for strategic commitment in teams at all levels. The chief strategy officer in the first organization noted,

We needed all employees to understand the bigger picture, ... and thus, that just doing your own job in splendid isolation, and doing an $\mathrm{OK}$ job on that, is not enough.... In an organization where there is so much interdependence, you can't have the performance on the level you want it to be if there is a big lack of alignment.

Similarly, the CEO underlined the importance of strategic consensus:

People see that that is part of a bigger process... so, what we want to achieve is more important than what I want. So, your people can say "OK, now I see, that is important, so I will give up my little project, so you can do yours because that is more important."

The CEO of the second organization said, "We can only make our strategy happen if we all work closely together."

\section{Data Collection and Respondents}

We collected our primary data through online surveys. Prior to the surveys, we interviewed key informants (the CEO and the chief strategy officer in the first and the CEO and 
the human resources (HR) manager in the second organization) and reviewed company documents to learn more about the organizational contexts. We retrieved information about manager-subordinate relationships from the companies' HR databases and used this to identify the teams. We verified that these teams had clear team boundaries through several checks with the HR departments. The teams and individuals that did not fit this definition were omitted from further analysis (i.e., administrative assistants, secretaries, external consultants, auditors). We identified 110 teams in the first organization and 54 teams in the second organization. In both organizations, each team was supervised by a separate manager, and managers did not supervise multiple teams. Teams in the first organization were middle- and operational-level teams; teams in the second were middle-management teams.

We secured TMT support in both organizations, as the organizations wanted to know more about their team strategic commitment. Before the survey, both CEOs sent an e-mail announcing the survey, emphasizing its importance and asking participants for their contribution. This e-mail was followed by a kickoff e-mail, which included a personalized link to the survey website, two reminders, and a final announcement of closure of the survey. In these e-mails, we assured confidentiality of the survey responses and underlined that the company could access the aggregated results only at the team level. These remedies reduce socialdesirability bias and increase the accuracy of the responses (Podsakoff, MacKenzie, \& Podsakoff, 2012). We also provided clear directions for filling out the questionnaire. We mitigated evaluation apprehension by emphasizing that there were no right or wrong answers. In addition, we located the survey items for independent and dependent variables separately where dependent variables followed the other items to mitigate consistency bias (Podsakoff, MacKenzie, Lee, \& Podsakoff, 2003).

We obtained responses from all 164 teams: 639 out of the 891 employees from the first organization and 316 responses out of 368 employees from the second (response rates of $72 \%$ and $86 \%$, respectively). We have not observed any meaningful differences in our model coefficients comparing early respondents to the full sample (Goodman \& Blum, 1996), which suggests nonresponse bias is not a serious threat.

We discarded six teams that had within-group response rates lower than $50 \%$. We did so because consensus is a group-level construct that requires a high within-group response rate and because low response may yield results that are not representative of the strategic consensus of the group as a whole (Allen, Stanley, Williams, \& Ross, 2007). The mean withingroup response rate for the remaining groups was $80.4 \%$. We further discarded 22 teams because their managers did not respond and we therefore were unable to match the team data with manager data. The teams we excluded from analysis did not differ from the teams in the sample in terms of any of the study variables.

The final sample consisted of 136 work teams: 88 work teams (536 individuals; $M=6.08$, $S D=3.78$ ) from the first organization and 48 work teams (266 individuals; $M=5.54, S D=$ 2.44) from the second organization. Team sizes ranged from 3 to 15 in the first organization and from 3 to 12 in the second organization. In the first organization, $79 \%$ of the respondents were men, and $48.1 \%$ had a bachelor's degree or higher. The respondents had an average work experience of 22.1 years $(S D=11.7)$ and had worked in their current function for an average of 5.8 years $(S D=7.6)$. In the second organization, $82 \%$ of the respondents were men, and $50 \%$ had a bachelor's degree or higher. The respondents were on average 47 years old $(S D=7.4)$ and had worked in the organization for 13 years $(S D=10.7)$. 
To determine whether the data from the first and second organizations could be pooled, we performed Chow tests (Chow, 1960). These tests evaluated whether the regression coefficients estimated over one organization are equal to the coefficients estimated over the other one. Chow tests failed to reject the null hypotheses that the regression coefficients are different $-F(9,118)=1.13, p=.654$, for strategic consensus; $F(10,116)=0.61, p=.200$ for strategic commitment - and assured us that we could merge the data from the two organizations for our analyses.

\section{Measures}

Strategic commitment. To measure team strategic commitment (i.e., the team excluding the team manager), we used six Likert scale items from Wooldridge and Floyd (1990), as previously done by Dooley etal. (2000) and Parayitam and Dooley (2011). Respondents evaluated these items on 5-point scales. Sample items included "This strategy really inspires me to perform my very best at my job" and "I find it difficult to put effort toward this strategy" (reverse). In line with earlier research, a principal-components factor analysis yielded a single factor solution. This scale had satisfactory reliability $(\alpha=0.79)$. Mean $r w g(j)$ of 0.93 and the intraclass correlation (ICC[1] and ICC[2]) values of 0.12 and 0.61 supported aggregation to the team level by averaging the ratings of the team members (Bliese, 2000).

Strategic consensus. We measured team strategic consensus relying on company-specific strategic content because this is a better choice than using generic strategy items (Kellermanns etal., 2005). The TMTs in both organizations provided us a list of their organizational strategic priorities together with their explanations in detail (seven priorities in the first organization, 11 strategic priorities in the second). ${ }^{3}$ After presenting the set of strategic priorities and their explanations in the survey, we asked respondents to rate each strategic priority with respect to the importance that they attach to it. Because our interest is in the role of the team managers in creating strategic consensus and commitment in their teams, we refrained from including the managers in the calculation of strategic consensus. This would have confounded the measures in that manager understanding of the strategy would be included both in a predictor variable (strategic alignment) and in the criterion variable (consensus; cf. van Knippenberg \& Sitkin, 2013). Accordingly, we operationalized the degree of strategic consensus within each team by using the ratings of team members excluding the manager and applied Tarakci etal.'s (2014) $\alpha$ measure. ${ }^{4}$ We chose this method because of its ability to quantify the degree of consensus and to visualize the multiple dimensions of consensus (i.e., the degree, scope, content, and locus) within a team.

Team manager strategic alignment with the CEO. The CEO and team managers rated the organizational strategic priorities, too. To operationalize team manager strategic alignment, we used the Pearson correlation between the priority ratings of the team manager and CEO, following the suggestions of Kellermanns etal. (2005) and Tarakci etal. (2014). A higher correlation between ratings indicates higher strategic alignment.

Team manager visionary leadership. We used the three-item visionary leadership scale of Rafferty and Griffin (2004) to measure followers' perception of the visionary leadership of 
their manager. The lead-in for all of the items was "My leader...," and the items are listed as follows: "has a clear understanding of where we are going," "has a clear sense of where s/he wants our team to be in 5 years" and "has no idea where the organization is going" (reverse). Team members indicated their level of agreement with these statements on a 5-point Likert scale. This scale had good reliability $(\alpha=.82)$. To determine a manager's visionary leadership score, we averaged the ratings from his or her subordinates; the mean $r w g(j)$ of 0.83 and the ICC[1] and ICC[2] scores of 0.16 and 0.54 justified aggregation to the team level.

Control variables. We controlled for several covariates that may meaningfully affect the hypothesized relationships. First, we controlled for the strategic commitment of the team manager, because committed managers are expected to exert more effort in strategy implementation (Wooldridge \& Floyd, 1990), which may lead them to create greater consensus and commitment among their team members. We operationalized this measure through the same six items from Wooldridge and Floyd $(1990 ; \alpha=.80)$ that were used to determine team strategic commitment. Second, we controlled for team size, because team manager's visionary leadership might be more effective in small teams compared to large teams. Third, we controlled for the team's hierarchical distance from the TMT in the formal organizational structure. A higher score indicates a greater distance from the TMT and, hence, a lower hierarchical level in the organizational hierarchy. Since strategic awareness diminishes as the hierarchical distance of a team from the TMT increases (Hambrick, 1981; Wooldridge \& Floyd, 1990), team manager's visionary leadership efforts to establish commitment to the organizational strategy can be more cumbersome at lower levels. We also controlled for the average team tenure and team manager's tenure because employees and managers with longer tenure have been exposed to the organizational context longer, as such managers' visionary leadership may more easily lead to strategic consensus and commitment. Last, we controlled for company, since our sample consisted of data from two organizations.

\section{Validity and Reliability Tests}

We ascertained the discriminating and the convergent validity of the Likert-scaled constructs (visionary leadership and strategic commitment) through confirmatory factor analysis. The measurement model with all items set to load on their respective factors fits the data well $\left(\chi^{2}=117.36, d f=26\right.$, comparative fit index $[\mathrm{CFI}]=0.96$, Tucker-Lewis index $[\mathrm{TLI}]=$ 0.95 , root mean square error of approximation [RMSEA] $=0.05$ ). The factor loading of each item was greater than the cutoff value of 0.7 and was significant at the 0.01 level, thus indicating convergent validity for both constructs. The chi-square difference test $\left(\Delta \chi^{2}{ }_{\text {diff }}=813.57\right.$, $d f=1, p=.000)$ indicated that this model was a better fit than the model in where all items were set to load on a single latent construct $\left(\chi^{2}=930.93, d f=27, \mathrm{CFI}=0.63, \mathrm{TLI}=0.51\right.$, RMSEA $=0.20)$.

Despite following the common method remedy recommendations (Podsakoff et al., 2003, 2012), there may be concerns regarding common method bias. We believe there are several factors that mitigate the risk that common method variance explains our findings. Common method variance in survey research by and large revolves around percept-percept relationships for main effects, which is not the case in our study since we have a moderator and a 
mediator that are measured with different and separate methods. Also, the responses were averaged across team members or put into a computational measure, which reduces the threat of common method variance (Podsakoff etal., 2003). Moreover, core to our analysis is a moderated mediation, while the presence of common method variance would work against obtaining a significant interaction effect (McClelland \& Judd, 1993).

To further reduce concerns, we performed two ex post analyses to test for potential common method bias. First, we applied a split-group method. This method reduces common method variance by removing the same-source bias. Analyses in which data from mutually exclusive random subgroups were used for each Likert-scaled construct yielded the same conclusions regarding support for our hypotheses. Second, we created an uncorrelated latent common method factor on which all visionary leadership and strategic commitment items were allowed to load (Podsakoff et al., 2003). This factor had a variance of 1, and all its paths were constrained to have equal weights $\left(\chi^{2}=115.04, d f=25, \mathrm{CFI}=0.97, \mathrm{TLI}=0.95\right.$, RMSEA = 0.06). A comparison with the original model corroborated that the common method factor did not significantly contribute to the model since this model did not provide a better fit $\left(\Delta \chi_{\text {diff }}^{2}=2.32, d f=1, p=.127\right)$. The factor loadings of the common method factor were 0.27 . The common method variance was 0.072 , thus indicating a very low common method problem. These results from both ex post analyses suggest that common method bias did not pose any threat to our results.

\section{Analytical Approach}

We tested Hypothesis 1 with multiple regression analysis checking the main effect of team strategic consensus on team strategic commitment and Hypothesis 2 with hierarchical regression analysis entering the interaction effect between visionary leadership and team manager strategic alignment. Hypothesis 3 concerns moderated mediation (Edwards \& Lambert, 2007; Muller etal., 2005; Preacher etal., 2007), and we used statistical routines for moderated mediation developed by Preacher et al. (2007) to test it. We bootstrapped the conditional indirect effect for high and low values of the moderator and determined whether the resulting confidence intervals (CIs) exclude zero. We also checked regions of significance for the conditional indirect effect by Johnson-Neyman approach and bootstrapping.

\section{Results}

Table 1 presents descriptive statistics and correlations. In line with our core moderation argument, the correlation between visionary leadership and strategic consensus is not significant $(r=.06, p=.510)$. We also note that the moderator variable team manager strategic alignment with the CEO is not significantly correlated with the independent variable visionary leadership $(r=.09, p=.250)$, which is preferable for a clearly interpretable interaction term (Aguinis, Edwards, \& Bradley, 2017). The correlations among focal study variables are below the threshold of 0.50 , and the largest variance inflation factor across all the regression models was 2.27, which relieve multicollinearity concerns. The Koenker tests for heteroskedasticity suggests there is no problem in terms of the homogeneity of residual variance in strategic commitment and strategic consensus models. Last, plotting the standardized residuals versus predicted values plots suggests there are no nonlinear patterns. 
Table 1

Descriptive Statistics and Correlations

\begin{tabular}{lcccccccccccc}
\hline Variable & $M$ & $S D$ & 1 & 2 & 3 & 4 & 5 & 6 & 7 & 8 & 9 & 10 \\
\hline 1. Team manager visionary leadership & 3.62 & 0.46 & - & & & & & & & & \\
2. Team manager strategic alignment & 0.27 & 0.34 & .09 & - & & & & & & & \\
$\quad$ with the CEO & & & & & & & & & & & \\
3. Team strategic consensus & 0.64 & 0.16 & .06 & .26 & - & & & & & \\
4. Team strategic commitment & 3.71 & 0.31 & .21 & .02 & .24 & - & & & & \\
5. Team Manager Visionary Leadership & 0.98 & 1.24 & .21 & .83 & .30 & .05 & - & & & & \\
$\quad$ × Team Manager Strategic & & & & & & & & & & & \\
Alignment With the CEO & & & & & & & & & & & \\
6. Team manager strategic commitment & 4.01 & 0.49 & .06 & -.03 & -.08 & .31 & .00 & - & & & \\
7. Team size & 5.89 & 3.37 & -.07 & -.00 & -.06 & -.09 & -.00 & .05 & - & & \\
8. Team level & 3.93 & 0.94 & -.19 & -.18 & .00 & -.29 & -.20 & -.15 & .16 & - & \\
9. Average team tenure & 8.49 & 6.21 & -.17 & -.16 & .02 & .11 & -.20 & -.14 & -.00 & .28 & - & \\
10. Team manager tenure & 6.28 & 8.14 & -.05 & -.07 & .09 & .27 & -.09 & -.08 & -.08 & .19 & .40 & - \\
11. Company & 0.35 & 0.48 & -.12 & -.30 & -.01 & .40 & -.31 & .05 & -.08 & .07 & .46 & .43 \\
\hline
\end{tabular}

Note: $N=136$. Correlations larger than $.17(.28)$ are significant at the level of $.05(.01)$, two-tailed test.

Table 2 presents the results of the hierarchical regression analyses. The dependent variable of the first two models in Table 2 is team strategic commitment, and that of the next three is team strategic consensus. Hypothesis 1 predicts the positive effect of team strategic consensus on strategic commitment. Model 1 is the control variable model for team strategic commitment and accounts for $32 \%$ of the variance. The results show that teams with more strategically committed managers $(b=0.14, S E=0.05, p=.002)$, at higher levels of the hierarchy $(b=-0.10, S E=0.03, p=.000)$, and from the second company $(b=0.21, S E=$ $0.06, p=.001$ ) have higher levels of strategic commitment. Model 2 tests the effect of strategic consensus on strategic commitment $(b=0.44, S E=0.13, p=.001)$, which supports Hypothesis 1.5

Hypothesis 2 predicts that team manager strategic alignment with the CEO moderates the relationship of team manager visionary leadership with team strategic consensus. Model 3 includes the control variables and accounts for $2 \%$ of the variance. In Model 3, we entered the main effects of visionary leadership $(b=0.02, S E=0.03, p=.604)$ and team manager's strategic alignment with the CEO $(b=0.13, S E=0.04, p=.003)$, accounting for an additional variance of $7 \%(p=.01)$. The significant interaction between team manager strategic alignment and team manager visionary leadership in Model $5(b=0.24, S E=0.07$, $p=.001)$ provides support for Hypothesis $2\left(\Delta R^{2}=0.08, p=.001\right)$. Figure 2 graphically depicts this interaction effect (Aiken \& West, 1991). As predicted, team manager visionary leadership is positively related to team strategic consensus when team manager strategic alignment is high (when strategic alignment is one standard deviation above the mean, the gradient of the simple slope is $0.08, t=2.34, p=.021$ ). In contrast, when team manager strategic alignment is low (one standard deviation below the mean), team manager visionary leadership is negatively related to team strategic consensus (the gradient of the simple slope is $-0.077, t=-1.96, p=.052$ ). 
Table 2

Multiple Regression Results

\begin{tabular}{|c|c|c|c|c|c|c|c|c|c|c|c|c|c|c|c|}
\hline \multirow[b]{3}{*}{ Variable } & \multicolumn{6}{|c|}{ Team Strategic Commitment } & \multicolumn{9}{|c|}{ Team Strategic Consensus } \\
\hline & \multicolumn{3}{|c|}{ Model 1} & \multicolumn{3}{|c|}{ Model 2} & \multicolumn{3}{|c|}{ Model 3} & \multicolumn{3}{|c|}{ Model 4} & \multicolumn{3}{|c|}{ Model 5} \\
\hline & $b$ & $S E$ & $p$ & $b$ & $S E$ & $p$ & $b$ & $S E$ & $p$ & $b$ & $S E$ & $p$ & $b$ & $S E$ & $p$ \\
\hline Intercept & 3.41 & 0.22 & .000 & 3.08 & 0.24 & .000 & 0.72 & 0.15 & .000 & 0.58 & 0.19 & .003 & 0.78 & 0.2 & .000 \\
\hline \multicolumn{16}{|l|}{ Controls } \\
\hline $\begin{array}{l}\text { Team manager strategic } \\
\text { commitment }\end{array}$ & 0.14 & 0.05 & .002 & 0.15 & 0.05 & .001 & -0.02 & 0.03 & .482 & -0.02 & 0.03 & .502 & -0.03 & 0.03 & .241 \\
\hline Team size & 0.00 & 0.01 & .931 & 0.00 & 0.01 & .676 & -0.00 & 0.00 & .553 & -0.00 & 0.00 & .527 & -0.00 & 0.00 & .440 \\
\hline Team level & -0.10 & 0.03 & .000 & -0.09 & 0.02 & .000 & -0.00 & 0.02 & .850 & 0.01 & 0.02 & .627 & 0.01 & 0.02 & .714 \\
\hline Average team tenure & -0.00 & 0.00 & .620 & -0.00 & 0.00 & .586 & 0.00 & 0.00 & .886 & -0.00 & 0.00 & .999 & 0.00 & 0.00 & .615 \\
\hline Team manager tenure & 0.01 & 0.00 & .030 & 0.01 & 0.00 & .052 & 0.00 & 0.00 & .265 & 0.00 & 0.00 & .485 & 0.00 & 0.00 & .356 \\
\hline Company & 0.21 & 0.06 & .001 & 0.21 & 0.06 & .001 & -0.03 & 0.04 & .492 & 0.01 & 0.04 & .776 & 0.00 & 0.04 & .938 \\
\hline \multicolumn{16}{|l|}{ Main effects } \\
\hline $\begin{array}{l}\text { Team manager visionary } \\
\text { leadership }\end{array}$ & & & & & & & & & & 0.02 & 0.03 & .604 & -0.06 & 0.04 & .126 \\
\hline $\begin{array}{l}\text { Team manager strategic } \\
\text { alignment with the CEO }\end{array}$ & & & & & & & & & & 0.13 & 0.04 & .003 & -0.73 & 0.25 & .004 \\
\hline Team strategic consensus & & & & 0.44 & 0.13 & .001 & & & & & & & & & \\
\hline \multicolumn{16}{|l|}{ Interaction effect } \\
\hline $\begin{array}{l}\text { Team Manager Visionary } \\
\text { Leadership } \times \text { Team } \\
\text { Manager Strategic } \\
\text { Alignment With the CEO }\end{array}$ & & & & & & & & & & & & & 0.24 & 0.07 & .001 \\
\hline$\Delta R^{2}$ & & & & 0. & 05 & & & & & 0.0 & & & 0.0 & 08 & \\
\hline$\Delta F$ & & & & 11.3 & & .001 & & & & 4.3 & & .010 & 12. & & .001 \\
\hline$R^{2}$ & 0.3 & & & 0.3 & 37 & & 0.0 & & & 0.0 & & & 0.1 & 17 & \\
\hline Adjusted $R^{2}$ & 0.2 & & & 0.3 & 34 & & 0.0 & & & 0.0 & & & 0.1 & 12 & \\
\hline Model $F$ & 10.5 & & .000 & 11.3 & & .000 & 0.5 & & .788 & 1.9 & & .066 & 3.5 & 57 & .002 \\
\hline
\end{tabular}

Note: $N=136$.

Hypothesis 3 posits that team manager strategic alignment moderates the indirect effect of team manager visionary leadership on team strategic commitment through team strategic consensus. This implies that the conditional indirect effect of visionary leadership on strategic commitment should be different for teams with high versus low levels of team manager strategic alignment. Following Preacher etal.'s (2007) recommendation, we constructed bias-corrected CIs based on 5,000 random samples by using their bootstrap procedure. We operationalized high and low levels of alignment as one standard deviation above and below the mean. The $95 \%$ bias-corrected bootstrapping CIs for the conditional indirect effects both at the low (CI: $[-0.11,-0.02])$ and the high (CI: $[0.01,0.10])$ values of team manager strategic alignment excluded zero, and the signs of the indirect effects were in line with our prediction, providing support for Hypothesis 3.

To further probe the significance of the conditional indirect effect at different values of the moderator (Preacher etal., 2007), we constructed CIs both by the Johnson-Neyman technique and by bootstrapping the conditional indirect effect 5,000 times. The Johnson-Neyman technique concluded the conditional indirect effect is negative and significant at the $5 \%$ level when manager strategic alignment is smaller than -0.27 , and positive and significant when it 
Figure 2

The Interaction Effect of a Team Manager's Visionary Leadership and His or Her Strategic Alignment With the CEO on the Degree of Team Strategic Consensus

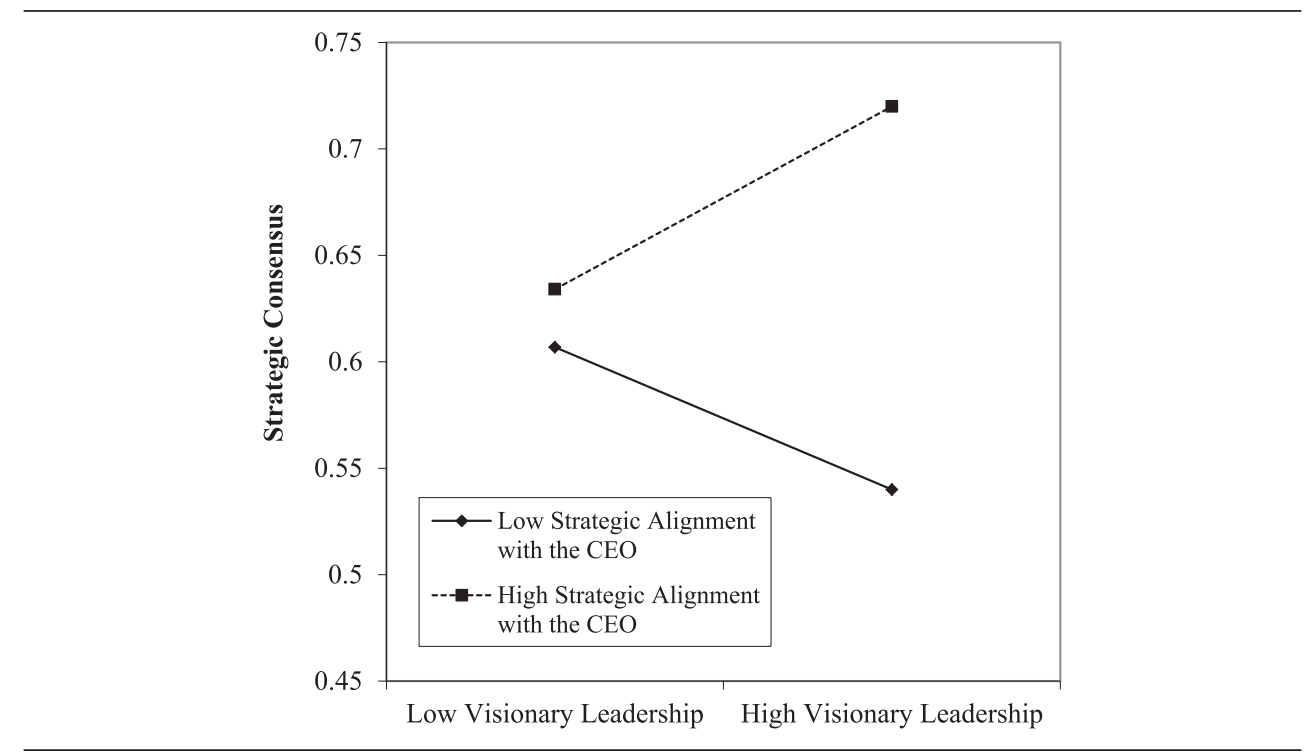

is larger than 0.60. Similarly, the bootstrapped CIs were negative and excluded zero when manager strategic alignment is smaller than -.10, and positive and excluded zero when it is larger than 0.5. Providing finer-grained information about the conditional indirect effect, both techniques further corroborate Hypothesis 3.

\section{Robustness Checks}

We conducted several robustness checks. First, we checked the sensitivity of our findings to alternative measures. We conducted our analysis using alternative measures of team strategic consensus and manager strategic alignment. We used the average of standard deviations of strategy item prioritizations multiplied by -1 for strategic consensus (Kellermanns etal., 2005 ) and the Euclidean distance multiplied by -1 for manager strategic alignment (Colbert et al., 2008). The analysis conducted using these alternative measures produced similar conclusions regarding the hypotheses tested as the results described in the previous section. This is in line with Tarakci et al. (2014), who indicate that the $\alpha$ measure behaves similarly to other measures of consensus. We repeated our analysis using manager strategic alignment with the entire TMT instead of with just the CEO because the TMT may be more representative than the CEO with respect to the organization's strategic direction. In both organizations, the high degree of within-group consensus in the TMT implied that the priorities of the TMT members were similar, resulting in a high correlation between manager alignment with the TMT and manager alignment with the CEO $(r=.84)$. We operationalized manager alignment with the TMT with the same correlational measure as we did for alignment with the CEO, in which the TMT prioritizations were obtained through the prototypical group member analysis of Tarakci etal. (2014). ${ }^{6}$ We obtained similar results with this operationalization. 
Second, to ensure our results do not suffer from endogeneity, we utilized instrumental variables for both our consensus and alignment constructs. We used ivpack package Version 1.2 in R (Jiang \& Small, 2015) to calculate two-stage least squares regressions (Hamilton \& Nickerson, 2003). We used team tenure diversity and age diversity as instruments for strategic consensus and used manager's organizational identification as an instrument for team manager strategic alignment (Antonakis, Bendahan, Jacquart, \& Lalive, 2014). Team tenure and age diversity are operationalized by coefficient of variation (Harrison \& Klein, 2007). Manager's organizational identification is measured by Mael and Ashforth's (1992) scale $($ Cronbach's alpha $=.87)$.

Homogeneity on team members' background characteristics has been vastly studied as an antecedent of strategic consensus (e.g., Dess \& Priem, 1995; Iaquinto \& Fredrickson, 1997; Knight etal., 1999; Priem, 1990) because similarity between team members may engender cohesiveness and consensus (van Knippenberg \& Schippers, 2007). For instance, Knight et al. (1999) reported a meaningful positive association between tenure diversity and strategic consensus. Accordingly, weak-instruments $F$ tests assure that both tenure, $F(1,126)=6.27$, $p=.014$, and age diversity, $F(1,126)=3.189, p=.067$, are good instruments, individually. Additionally, one would not expect that team members would be more willing to exert effort toward realization of organizational strategies because they have similar tenure or age. Hence, both are conceptually exogeneous to strategic commitment. Sargan's test for instrument endogeneity assures that these instruments are indeed exogeneous and uncorrelated with the model residuals $(J$ statistic $=0.014, p=.904)$. The weak-instruments $F$ test assures that both are good instruments, $F(2,125)=4.93, p=.009$, and the Wu-Hausman test, $F(1,125)=0.00, p=.932$, suggests that our results do not suffer from endogeneity (Antonakis etal., 2014).

Organizational identification represents individual self-definition as a member of the organization (Ashforth, Harrison, \& Corley, 2008). Managers with high organizational identification are more likely to internalize the organization's interests and goals as their own (Ashforth etal., 2008). Thus, it is conceptually relevant to strategic alignment. The weakinstruments $F$ test rejects the null hypothesis that organization identification is a weak instrument, $F(1,127)=4.86, p=.029$. Furthermore, managers' organizational identification is not included in the nomological network of strategic consensus (Kellermanns et al., 2005, 2011); thus it is exogeneous to strategic consensus. Because we had only a single instrument of sufficient strength for strategic alignment, we checked the correlation between manager's organizational identification and the residuals associated with strategic consensus $(r=-.06$, $p=.464$ ), following Semadeni, Withers, and Trevis Certo (2014). This insignificant correlation is in line with our theoretical arguments regarding instrument exogeneity. After confirming that organizational identification is a good instrument, the Wu-Hausman test results showed that the ordinary least squares (OLS) model estimates do not significantly differ from the instrumental variable model estimates, $F(1,126)=0.70, p=.403$. Therefore, we conclude that our OLS results do not suffer from serious endogeneity concerns and can be reported.

\section{Supplemental Analyses}

We conducted two supplemental analyses to get a better sense of how aligned and misaligned managers' communication about strategy impacts the strategic consensus in their teams. First, we visualized the content of consensus (what the actual beliefs of team members are) together with its degree, locus (which members participate in consensus), and scope 
(how many members participate in consensus) (see Markoczy, 2001; Tarakci etal., 2014; Wooldridge \& Floyd, 1989) in an exemplar selection of teams. We were particularly interested to see whether team managers that generate a high degree of strategic consensus in their teams do so on strategic content that is aligned with the CEO's strategic understanding or that is misaligned. Second, we conducted 16 semistructured post hoc interviews with eight manager-employee dyads from the first organization to provide some context to what managers do and how that is perceived by their followers. This provides some further anecdotal insights to the observed visual patterns of strategic consensus.

For the visualization, we performed a median split based on team manager visionary leadership and team manager strategic alignment, which yielded four subgroups of teams corresponding to the quadrants in Figure 3. We visualized the multiple dimensions of consensus with strategic consensus mapping for an exemplar team from each of these subgroups (Tarakci etal., 2014). ${ }^{7}$ Important for the interpretation of Figure 3 is that this method visualizes team members as vectors and strategic priorities as points, and the proximity of two vectors indicates the similarity of two members in terms of their views of these strategic priorities. As such, the spread of all vectors represents the strategic consensus within the team (wider spread means lower consensus). To better understand the different patterns of strategic consensus in the exemplar teams, we included the team manager and the CEO in the visualizations to identify their positions with respect to the team members and to each other.

In Panels (a) and (b) of Figure 3, the team manager and the CEO vectors are close to each other, indicating a high degree of strategic alignment between them. The ideal case for successful strategy implementation seems to be depicted in Panel (b). Here, the manager has strong visionary leadership and is strategically aligned with the CEO. The spread of team members' vectors is narrow, indicating a high degree of consensus in the team. The content of consensus is on the desired strategic priorities of the CEO, since all vectors are close to that vector. Regarding the locus and scope of consensus, we observe that all of the relevant actors participate in the consensus; thus this pattern signals "acting as one team." In contrast, Panel (a) shows that although the manager shares the views of the CEO, he or she exhibits low levels of visionary leadership and fails to create consensus in his or her team. There is a wider spread among the team member vectors than that of Panel (b), indicating low team strategic consensus, which suggests that here an "aligned manager fails to persuade followers." Moreover, the CEO's and several team members' vectors are almost orthogonal, which suggests that many members of this team are not aligned with the strategy as formulated by the CEO.

In Panels (c) and (d) of Figure 3, the manager and CEO vectors are far from each other, indicating low strategic alignment between them. In Panel (c), the manager's visionary leadership is low, and his or her vector does not line up with those of the team. The team vectors do not come close to the CEO's nor the manager's vectors; thus here, the team manager is "misaligned and unpersuasive." Moreover, the pattern of vectors suggests that a subset of the team agrees on different strategic priorities than the CEO's, similar to Panel (a). Panel (d) represents the most striking, but possibly also the least desirable, case in terms of strategy implementation. Here, team members exhibit segmentation in terms of their views, as if the team is "one boat with two captains." The team has low strategic consensus, where most of the team members are closer to their manager and thus agree with his or her strategic view that is not aligned with the view of the CEO, but some of them hold opinions that are more similar to those of the CEO. 
Figure 3

Example Visualizations of Strategic Consensus Through Strategic Consensus Mapping

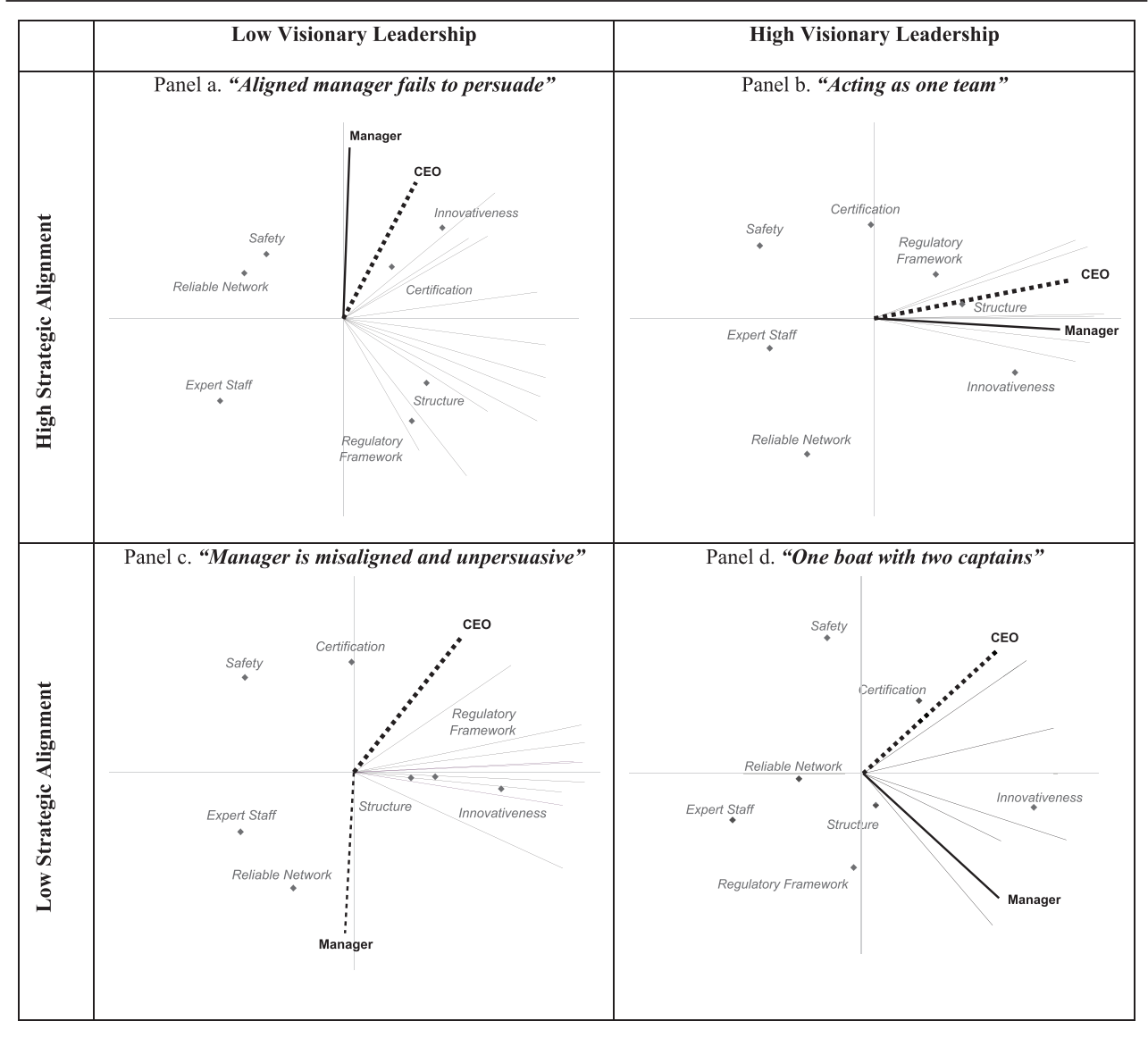

Note: The panels visualize within-group consensus for a sample of four teams. Biplots pertain to vector model of unfolding on the respondents' ratings. Vectors represent team members and points represent strategic priorities. An orthogonal projection of a point onto a vector indicates the rating of that particular strategic priority by that team member such that longer projections in the positive direction represent higher importance. This projection demonstrates the content of consensus (the actual views of team members). If two vectors are close to each other, those two team members share a similar view. The spread of all of the vectors (excluding the manager's and CEO's vectors) represents the degree of strategic consensus within the team. The locus (who participates in consensus and who does not) and scope (how many members participate in it) of consensus can also be interpreted from the positions of vectors in the biplots.

With an understanding of these different visual patterns of strategic consensus in the four subgroups, we interviewed manager-employee dyads where the manager scored in the extremes in terms of visionary leadership and strategic alignment with the CEO, to have a good illustration of the differences between such managers (Yin, 2013). These interviews revealed that manager and employee explanations of how the manager communicated about 
Table 3

(Mis)aligned Managers With Low/High Visionary Leadership Exemplars

\begin{tabular}{|c|c|c|}
\hline Alignment & Low Visionary Leadership & High Visionary Leadership \\
\hline $\begin{array}{l}\text { High strategic } \\
\text { alignment }\end{array}$ & $\begin{array}{l}\text { Panel (a). Aligned manager fails to persuade } \\
\text { Manager: "They're [my subordinates] probably to a } \\
\text { lesser extent aware of the strategies than me, because } \\
\text { their base activities are clear. [To connect strategy to } \\
\text { their jobs] I make and set specific rules for them." } \\
\text { Employee: "But about the real content [of the } \\
\text { strategies], we do not really talk with our manager. } \\
\text { With him, it is more about the operational side.... } \\
\text { We, as a team, actually believe that we should do } \\
\text { that [discussing the real content of strategy with the } \\
\text { manager] more often, to really evaluate with our } \\
\text { manager and the team about our work." }\end{array}$ & $\begin{array}{l}\text { Panel (b). Acting as one team } \\
\text { Manager: "If you're implementing } \\
\text { a new strategy ..., there are } \\
\text { often people who will say, 'In } \\
\text { my daily job, there is something } \\
\text { else going on, you should pay } \\
\text { attention to that.' ... It's hard } \\
\text { to show ... that it's in fact an } \\
\text { entire organization that they } \\
\text { are working for. It's not about } \\
\text { the individual scores of the } \\
\text { employee or the department- } \\
\text { those can be very high-but that } \\
\text { it's about the functioning of an } \\
\text { entire organization." } \\
\text { Employee: "He [the team manger] } \\
\text { does not give it [strategy] his } \\
\text { blend; it is what it is. We [team } \\
\text { members] all know what it is } \\
\text { about, and work for it." }\end{array}$ \\
\hline $\begin{array}{l}\text { Low strategic } \\
\text { alignment }\end{array}$ & $\begin{array}{l}\text { Panel (c). Manager is misaligned and unpersuasive } \\
\text { Manager: "Some of my subordinates struggle } \\
\text { with formulating their direct contribution to the } \\
\text { organization.... One should try to find a connection } \\
\text { [between the team and the company strategy], but } \\
\text { already I have to struggle to see what's applicable for } \\
\text { my team." } \\
\text { Employee: "If the disagreement between my manager } \\
\text { and the organizational strategy becomes dysfunctional } \\
\text { for the team I would bypass my manager and complain } \\
\text { higher up.... I think my manager would eventually } \\
\text { have to and will submit to the company strategies.... } \\
\text { But anyways he's not the type to pursue such things." }\end{array}$ & $\begin{array}{l}\text { Panel }(\mathrm{d}) \text {. One boat with two } \\
\text { captains } \\
\text { Manager: "No, I'm not very } \\
\text { committed to the strategies of our } \\
\text { company. In my daily job, I don't } \\
\text { always see the added value of the } \\
\text { strategies." } \\
\text { Employee: "Well, we talk much } \\
\text { about strategy with our manager. } \\
\text { But I don't see a clear company } \\
\text { strategy. I rather chose to focus } \\
\text { on my daily tasks, and leave it } \\
\text { [strategy] for what it is." }\end{array}$ \\
\hline
\end{tabular}

strategy to the team were consistent with the patterns we observed in Figure 3, as can be seen from some exemplar quotes in Table 3. For instance, a manager from the subgroup "aligned manager fails to persuade" $\left(\mathrm{M}_{\mathrm{A}}\right)$ explained his strategic communication very differently from a manager in the subgroup "one boat with two captains" $\left(\mathrm{M}_{\mathrm{D}}\right)$.

$\mathrm{M}_{\mathrm{A}}$ : I'm part of the strategic process in our company.... I don't really discuss my strategic visions with my team.

$\mathrm{M}_{\mathrm{D}}$ : Often from a finance perspective, there are two scenarios: One, follow the strategy at stake, or two, focus on cost efficiency.... I think we [as a team] would definitely choose to go for Scenario 2.

Similarly, an employee from the subgroup "manager is misaligned and unpersuasive" $\left(\mathrm{E}_{\mathrm{C}}\right)$ explained his or her understanding of the organizational strategy very differently from an employee in the subgroup "acting as one team" $\left(\mathrm{E}_{\mathrm{B}}\right)$. 
$\mathrm{E}_{\mathrm{C}}$ : In my current team, long-term goals aren't really important.... There's a lot of issues from days past. Many of them [my teammates] just leave it [the strategy] for what it is.

$\mathrm{E}_{\mathrm{B}}$ : We hear about strategy from the upper management. My supervisor tells us about it, too. She helps us [team members] to see what it [the strategy] really means for us.

Overall, this exploratory visual analysis and the anecdotal qualitative evidence provide further support to our theoretical claim that managers that exhibit strong visionary leadership behaviors create strategic consensus and consequent strategic commitment in their teams only when they are strategically aligned. Because we adopted a multifaceted view of strategic consensus, we could observe that a high degree of strategic consensus does not necessarily indicate that the strategic consensus is on the right strategic content (i.e., as intended by the CEO; see Panels [a] and [c] but also [d]). This observation adds to our findings on the detrimental effects of misaligned managers and/or managers with low visionary leadership because it demonstrates that these managers may not only hamper strategic consensus in their teams, but they may also misalign a subset of their team in terms of the content of strategic consensus. The real-life quotes from both managers and employees support this observation by providing examples of how managers and employees perceive the strategy.

\section{Discussion}

This study builds on the visionary leadership and strategy process literatures to advance our understanding of how middle and lower-level managers' visionary leadership affects team strategic commitment. Consistent over two organizations, our findings highlight not only the positive influence of team manager visionary leadership in strategy implementation but also its until-now neglected detrimental effects - the "dark side" of visionary leadership. Thus, we advance our understanding of the role of team manager visionary leadership in strategy implementation. We proposed and showed that team manager visionary leadership is positively related to team strategic consensus and commitment only to the extent that the team manager is strategically aligned with the CEO. When strategic alignment with the CEO is low, team manager visionary leadership is negatively related to consensus and commitment. These findings have important implications for theory and practice.

\section{Theoretical Contributions}

The primary theoretical contribution of this study is that we challenge the view of visionary leadership as a purely positive phenomenon (Baum etal., 1998; Kirkpatrick et al., 2002; Shamir \& Howell, 1999; van Knippenberg \& Stam, 2014). Research in the leadership as well as in the strategic management domain has so far reported only on organizational and contextual variables that increase the positive effect of visionary leadership (van Knippenberg \& Stam, 2014), and research in strategic management has examined only top managers' visionary leadership (Baum etal., 1998; Elenkov etal., 2005; Westley \& Mintzberg, 1989). Although these efforts have contributed to our understanding of visionary leadership, they fail to capture that leaders at middle and lower levels may engage in counterproductive actions (Meyer, 2006), opportunism and linguistic influencing of strategic initiatives (Sillince \& Mueller, 2007), and foot dragging and sabotaging of strategy implementation (Guth \& MacMillan, 1986). We built on strategy research that explains why managers outside of the 
C-suite may often have different views of strategy than top managers (Burgelman, 1991; Guth \& MacMillan, 1986; Meyer, 2006; Wooldridge \& Floyd, 1990) and proposed that alignment between managers and the CEO is a so-far overlooked contingency pointing to the dark side of visionary leadership. Our study is the first to show the detrimental impact of managers' misaligned visionary leadership and does so for an outcome that is key in the strategy implementation process: team strategic commitment.

In identifying the moderating role of team manager strategic alignment, we provide a valuable extension to visionary leadership theory in the strategic management literature. The insight here is not just that visionary leadership may have a dark side but also that findings for visionary leadership at the top management level do not simply extrapolate to middle and lower-level managers - an important observation for a stream of research that so far focused only on CEO visionary leadership (Baum etal., 1998; Elenkov etal., 2005). Our findings on the dark side of visionary leadership among middle and lower-level managers also help address calls in leadership research to examine what "happens in the middle place - the location where upper-level initiatives are transformed into unit-level programs" (Balogun \& Johnson, 2004; DeChurch, Hiller, Murase, Doty, \& Salas, 2010: 1080; Floyd \& Wooldridge, 1992). It also addresses the skeptical question in the strategy process literature whether team managers' impact on strategy implementation is always positive (Balogun, 2003; Huy, 2011). Our study thus constitutes an important step forward in the development of a greater understanding of the role of team manager leadership in the strategy process. Future research can build on our findings to develop this more balanced understanding of the role of visionary leadership.

By conceptually and empirically analyzing the mechanism through which team manager visionary leadership affects team strategic commitment, we integrate visionary leadership and strategy process research and go beyond what each of those literatures alone could offer. Our focus on this mechanism is important for two reasons. First, by examining the alignment between the manager and the $\mathrm{CEO}$, we respond to the call from the strategy process literature to study the alignment of managers and TMTs (Balogun \& Johnson, 2004; Raes et al., 2011). Second, by examining alignment as moderating and strategic consensus as mediating variable, we were able to understand why previous studies did not find support for a positive relationship between change-specific leadership behavior and commitment to the change even when this relationship is widely assumed in the organizational development and change literature (e.g., Herold etal., 2008). We propose and find that the mixed signals from the CEO and a misaligned visionary manager about what the strategy is are bad for team strategic consensus and thus for team strategic commitment. Our analysis of this moderated mediation mechanism allows us to answer calls to strengthen the psychological grounding and practical usefulness of strategy theory along the lines of behavioral strategy (Hutzschenreuter \& Kleindienst, 2006; Powell etal., 2011). Future research can build on our integration of these literatures.

Our research also contributes to the literature on the strategic roles of the managers outside the C-suite (Floyd \& Lane, 2000; Floyd \& Wooldridge, 1992, 1997). While a substantial amount of work has been done regarding middle managers' upward strategic roles (championing and synthesizing, sensemaking; Tarakci, Ateş, Floyd, Ahn, \& Wooldridge, 2018; Wooldridge et al., 2008), their essential downward role of influencing the process and outcomes of strategic change has so far been largely neglected (Balogun \& Johnson, 2005; Huy, 2011). Our findings on the role of visionary leadership of team managers in creating strategic 
commitment in their teams speaks to the role of leadership in team managers' fulfillment of their downward strategic role. This understanding is important not just because managers at these levels of the organizational hierarchy have a large degree of freedom to shape their subordinates' strategy-related understandings and execution efforts. It is also important because their leadership is a more proximal influence on the efforts of the employees who actually put strategy into practice than leadership from top management. That is, if we are to understand how strategy implementation develops, we need to understand how managers and their teams at these levels develop their commitment to any top-down change plans (Balogun \& Johnson, 2005; Huy, 2011). Accordingly, we open up a new research avenue to investigate what turns these managers into downward champions of the organizational strategy.

\section{Managerial Implications}

Our results show that a lack of strategic alignment between a manager and CEO prevents managers from creating strategic consensus and commitment in their teams. Strategic alignment prevents managers from negatively influencing followers by communicating messages that differ from those of the top management. Therefore, top management should bring middle and lower-level managers "on board" with respect to their strategic vision by aligning these managers with the strategy. We should note that our data do not speak to how this can be achieved but do suggest that middle and lower management should not be charged with implementing the strategy before alignment is ensured. That said, once such strategic alignment is built, our findings suggest that team manager visionary leadership is a positive influence. Our results show that visionary leadership creates stronger strategic consensus and commitment in teams when managers are strategically aligned. Accordingly, with a keen eye for this precondition, organizations may boost strategy implementation by supporting their managers to become visionary leaders.

\section{Limitations and Future Research}

We recognize the limitations of our study. The correlational nature of our data does not allow us to draw conclusions regarding causality. There is a good conceptual case that the causal chain we propose is the most plausible, but only experimental research-a field experimental training intervention for instance to build team leader visionary leadership and strategic alignment — can speak more definitively to this issue.

The organizations we studied operate in relatively stable environments, which have been argued to benefit from high strategic consensus (Kellermanns et al., 2005; Priem, 1990). This environmental context may impose a boundary condition on our findings. Research underlines that consensus in rapidly changing environments may cause premature closure, whereas dissent encourages the expression of diverse opinions that may help make necessary changes to strategic initiatives (Wooldridge \& Floyd, 1989; but see Samba, van Knippenberg, \& Miller, 2018). That said, the evidence would suggest that on balance, strategic consensus is desirable for strategy implementation across the board (cf. Kellermanns etal., 2005; Markoczy, 2001). Once a strategy is formulated, efficient execution requires that organizational constituents have a shared understanding of the strategy, making consensus desirable even when the environment is unstable. In fact, Walter et al. (2013:319) suggest that "it is the 
fit between the environment and an organization's strategic priorities that matters for organizational performance and not so much the level of environmental uncertainty or dynamism per se." Whereas we would thus expect that in more dynamic environments our model would replicate, this is an issue for a future empirical test and not a conclusion that can be drawn on the basis of the current findings.

Similar to the vast majority of the literature on visionary leadership, our measure captured the perception that a vision is communicated but not the content of the vision (van Knippenberg $\&$ Stam, 2014). We recommend that future studies also adopt vision content as a fundamental variable in strategy process research, especially because our qualitative analyses suggest that the visionary leadership of a strategically misaligned manager can create a divide in the team in terms of the strategic understanding of the team members.

\section{Conclusion}

This study demonstrates how middle and lower-level managers can influence their teams' strategic consensus and strategic commitment through visionary leadership in strategy implementation. Our findings highlight a dark side to visionary leadership: strategically misaligned visionary leadership, which may derail strategy implementation efforts by diminishing teams' strategic consensus and commitment. Strategic alignment between managers and the $\mathrm{CEO}$ is found to be at the core of ensuring the benefits of visionary leadership for strategy implementation efforts of teams at the middle and lower levels of the organization that put strategy in practice.

\section{Notes}

1. To avoid confusion with use of the term strategic alignment to refer to alignment with the environment (Walter, Kellermanns, Floyd, Veiga, \& Matherne, 2013), we use the term team manager strategic alignment.

2. The data reported in this manuscript have been gathered as part of a larger data collection effort. While the data from the second organization is unique to this study, the data from the first organization have some, albeit minimal, overlap with the data with Tarakci, Ates, Porck, van Knippenberg, Groenen, and de Haas (2014) and Porck, van Knippenberg, Tarakci, Ates, Groenen, and de Haas (2018). Tarakci et al. use a subsample of nine teams to illustrate a novel methodology. Porck et al. use the dyadic between-team data to study organizational and group identification's effects on intergroup strategic consensus.

3. To ascertain that the difference in number of priorities between the two organizations did not affect the consensus measure, we did a post hoc test. For the second organization, which had 11 priorities, we compared for each team its observed consensus measures with the average measure obtained from randomly removing four priorities 1,000 times. A paired $t$ test comparing the equality of the observed and simulated means across teams was not significant $(t$ value $=1.15, p=.25$, two tailed $)$, which suggests that the number of priorities did not affect the strategic consensus measure.

4. This method employs a vector model of unfolding on the respondents' strategic priority ratings for each team, then operationalizes consensus as the length of the average component loadings vector. A high $\alpha$ indicates a high level of consensus in a team with respect to team members' views of strategic priorities. This measure is obtained in statistical package programs (SPSS, SAS, STATA, R) by a principal components analysis of respondents' strategic priority ratings, where the respondents are the columns and strategic priorities are the rows. The squares of the average component loadings in both dimensions are summed, and the square root of this sum is the $\alpha$. For visual interpretation, Tarakci etal. (2014) suggest a rotation of component loadings with the average component loading in the second dimension set to zero (this is done after the measure is obtained and does not affect the value of $\alpha$ ). An online tool to compute $\alpha$ is freely available at https://mtarakci.shinyapps.io/consensus/.

5. The models without controls support our hypotheses in a similar fashion to the models with controls. 
6. The prototypical group member best represents the team opinion and is obtained by rotating the team members' component loading matrix in a way that coincides the average vector of component loadings with the first dimension by setting the average component loading in the second dimension to zero. Then, the prototypical group member's strategy prioritizations can be obtained by projecting the object scores of strategy items onto the rotated first axis.

7. Although each team has a unique visualization, we observe similar patterns within each subgroup of Figure 3. For illustrative purposes, we chose to depict only one team for each subgroup.

\section{References}

Aguinis, H., Edwards, J. R., \& Bradley, K. J. 2017. Improving our understanding of moderation and mediation in strategic management research. Organizational Research Methods, 20: 665-685.

Aiken, L. S., \& West, S. G. 1991. Multiple regression: Testing and interpreting interactions. Newbury Park, CA: SAGE.

Allen, N. J., Stanley, D. J., Williams, H. M., \& Ross, S. J. 2007. Assessing the impact of nonresponse on work group diversity effects. Organizational Research Methods, 10: 262-286.

Amason, A. C. 1996. Distinguishing the effects of functional and dysfunctional conflict on strategic decision making: Resolving a paradox for top management teams. Academy of Management Journal, 39: 123-148.

Antonakis, J., Bendahan, S., Jacquart, P., \& Lalive, R. 2014. Causality and endogeneity: Problems and solutions. In D. V. Day (Ed.), The Oxford handbook of leadership and organizations, Vol. 1: 93-117. New York: Oxford University Press.

Ashforth, B. E., Harrison, S. H., \& Corley, K. G. 2008. Identification in organizations: An examination of four fundamental questions. Journal of Management, 34: 325-374.

Balogun, J. 2003. From blaming the middle to harnessing its potential: Creating change intermediaries. British Journal of Management, 14: 69-83.

Balogun, J., \& Johnson, G. 2004. Organizational restructuring and middle manager sensemaking. Academy of Management Journal, 47: 523-549.

Balogun, J., \& Johnson, G. 2005. From intended strategies to unintended outcomes: The impact of change recipient sensemaking. Organization Studies, 26: 1573-1601.

Baum, J. R., Locke, E. A., \& Kirkpatrick, S. A. 1998. A longitudinal study of the relation of vision and vision communication to venture growth in entrepreneurial firms. Journal of Applied Psychology, 83: 43-54.

Beer, M., \& Eisenstat, R. A. 2000. The silent killers of strategy implementation and learning. Sloan Management Review, 41: 29-40.

Bliese, P. D. 2000. Within-group agreement, non-independence, and reliability. In K. J. Klein \& S. W. J. Kozlowski (Eds.), Multilevel theory, research and methods in organizations: 349-381. San Francisco: Jossey-Bass.

Boal, K., \& Hooijberg, R. 2001. Strategic leadership research: Moving on. Leadership Quarterly, 11: 515-549.

Bourgeois, L. 1980. Performance and consensus. Strategic Management Journal, 1: 227-248.

Burgelman, R. A. 1991. Intraorganizational ecology of strategy making and organizational adaptation: Theory and field research. Organization Science, 2: 239-262.

Cannella, A. A., \& Monroe, M. J. 1997. Contrasting perspectives on strategic leaders: Toward a more realistic view of top managers. Journal of Management, 23: 213-237.

Cannon-Bowers, J. A., Salas, E., \& Converse, S. 2001. Shared mental models in expert team decision making. In N. J. Castellan (Ed.), Individual and group decision making: 221-246. Hillsdale, NJ: Lawrence Erlbaum.

Carson, J. B., Tesluk, P. E., \& Marrone, J. A. 2007. Shared leadership in teams: An investigation of antecedent conditions and performance. Academy of Management Journal, 50: 1217-1234.

Carton, A. M., Murphy, C., \& Clark, J. R. 2014. A (blurry) vision of the future: How leader rhetoric about ultimate goals influences performance. Academy of Management Journal, 57: 1544-1570.

Chow, G. C. 1960. Tests of equality between sets of coefficients in two linear regressions. Econometrica: Journal of the Econometric Society, 28: 591-605.

Clegg, S., Courpasson, D., \& Phillips, N. 2006. Power and organizations. London: SAGE.

Coch, L., \& French, J. R., Jr. 1948. Overcoming resistance to change. Human Relations, 1: 512-532.

Colbert, A. E., Kristof-Brown, A. L., Bradley, B. H., \& Barrick, M. R. 2008. CEO transformational leadership: The role of goal importance congruence in top management teams. Academy of Management Journal, 51: 81-96.

Currie, G., \& Procter, S. J. 2005. The antecedents of middle managers' strategic contribution: The case of a professional bureaucracy. Journal of Management Studies, 42: 1325-1356. 
DeChurch, L. A., Hiller, N. J., Murase, T., Doty, D., \& Salas, E. 2010. Leadership across levels: Levels of leaders and their levels of impact. Leadership Quarterly, 21: 1069-1085.

Dess, G. G. 1987. Consensus on strategy formulation and organizational performance: Competitors in a fragmented industry. Strategic Management Journal, 8: 259-277.

Dess, G. G., \& Origer, N. K. 1987. Environment, structure, and consensus in strategy formulation: A conceptual integration. Academy of Management Review, 12: 313-330.

Dess, G. G., \& Priem, R. L. 1995. Consensus-performance research: Theoretical and empirical extensions. Journal of Management Studies, 32: 401-417.

Dooley, R. S., Fryxell, G. E., \& Judge, W. Q. 2000. Belaboring the not-so-obvious: Consensus, commitment, and strategy implementation speed and success. Journal of Management, 26: 1237-1257.

Edwards, J. R., \& Lambert, L. S. 2007. Methods for integrating moderation and mediation: A general analytical framework using moderated path analysis. Psychological Methods, 12: 1-22.

Elenkov, D. S., Judge, W., \& Wright, P. 2005. Strategic leadership and executive innovation influence: An international multi-cluster comparative study. Strategic Management Journal, 26: 665-682.

Fedor, D. B., Caldwell, S., \& Herold, D. M. 2006. The effects of organizational changes on employee commitment: A multilevel investigation. Personnel Psychology, 59: 1-29.

Floyd, S. W., \& Lane, P. J. 2000. Strategizing throughout the organization: Managing role conflict in strategic renewal. Academy of Management Review, 25: 154-177.

Floyd, S. W., \& Wooldridge, B. 1992. Middle management involvement in strategy and its association with strategic type: A research note. Strategic Management Journal, 13: 153-167.

Floyd, S. W., \& Wooldridge, B. 1997. Middle management's strategic influence and organizational performance. Journal of Management Studies, 34: 465-485.

Floyd, S. W., \& Wooldridge, B. 1999. Knowledge creation and social networks in corporate entrepreneurship: The renewal of organizational capability. Entrepreneurship Theory and Practice, 23: 123-144.

Goleman, D. 2000. Leadership that gets results. Harvard Business Review, 78: 78-90.

González-Benito, J., Aguinis, H., Boyd, B. K., \& Suárez-González, I. 2012. Coming to consensus on strategic consensus: A mediated moderation model of consensus and performance. Journal of Management, 38: 1685-1714.

Goodman, J. S., \& Blum, T. C. 1996. Assessing the non-random sampling effects of subject attrition in longitudinal research. Journal of Management, 22: 627-652.

Greer, L. L., Homan, A. C., De Hoogh, A. H., \& Den Hartog, D. N. 2012. Tainted visions: The effect of visionary leader behaviors and leader categorization tendencies on the financial performance of ethnically diverse teams. Journal of Applied Psychology, 97: 203-213.

Griffin, M. A., Parker, S. K., \& Mason, C. M. 2010. Leader vision and the development of adaptive and proactive performance: A longitudinal study. Journal of Applied Psychology, 95: 174-182.

Guth, W. D., \& MacMillan, I. C. 1986. Strategy implementation versus middle management self-interest. Strategic Management Journal, 7: 313-327.

Hailey, V. H., \& Balogun, J. 2002. Devising context sensitive approaches to change: The example of Glaxo Wellcome. Long Range Planning, 35: 153-178.

Hambrick, D. C. 1981. Environment, strategy, and power within top management teams. Administrative Science Quarterly, 26: 253-275.

Hambrick, D. C., \& Mason, P. A. 1984. Upper echelons: The organization as a reflection of its top managers. Academy of Management Review, 9: 193-206.

Hamilton, B. H., \& Nickerson, J. A. 2003. Correcting for endogeneity in strategic management research. Strategic Organization, 1: 51-78.

Harrison, D. A., \& Klein, K. J. 2007. What's the difference? Diversity constructs as separation, variety, or disparity in organizations. Academy of Management Review, 32: 1199-1228.

Herold, D. M., Fedor, D. B., Caldwell, S., \& Liu, Y. 2008. The effects of transformational and change leadership on employees' commitment to a change: A multilevel study. Journal of Applied Psychology, 93: 346-357.

Hunt, J. G. 1991. Leadership: A new synthesis. Newbury Park, CA: SAGE.

Hutzschenreuter, T., \& Kleindienst, I. 2006. Strategy-process research: What have we learned and what is still to be explored. Journal of Management, 32: 673-720.

Huy, Q. N. 2002. Emotional balancing of organizational continuity and radical change: The contribution of middle managers. Administrative Science Quarterly, 47: 31-69. 
Huy, Q. N. 2011. How middle managers' group-focus emotions and social identities influence strategy implementation. Strategic Management Journal, 32: 1387-1410.

Iaquinto, A. L., \& Fredrickson, J. W. 1997. Top management team agreement about the strategic decision process: A test of some of its determinants and consequences. Strategic Management Journal, 18: 63-75.

Ibarra, H., \& Obodaru, O. 2009. Women and the vision thing. Harvard Business Review, 87: 62-70.

Jiang, Y., \& Small, D. 2015. ivpack: Instrumental variable analysis. R package Version 1.2. Retrieved from https:// cran.r-project.org/web/packages/ivpack/index.html

Kellermanns, F. W., Walter, J., Floyd, S. W., Lechner, C., \& Shaw, J. C. 2011. To agree or not to agree? A metaanalytical review of strategic consensus and organizational performance. Journal of Business Research, 64: 126-133.

Kellermanns, F. W., Walter, J., Lechner, C., \& Floyd, S. W. 2005. The lack of consensus about strategic consensus: Advancing theory and research. Journal of Management, 31: 719-737.

Ketokivi, M., \& Castaner, X. 2004. Strategic planning as an integrative device. Administrative Science Quarterly, 49: 337-365.

Kirkman, B. L., \& Rosen, B. 1999. Beyond self-management: Antecedents and consequences of team empowerment. Academy of Management Journal, 42: 58-74.

Kirkpatrick, S. A., Wofford, J., \& Baum, J. R. 2002. Measuring motive imagery contained in the vision statement. Leadership Quarterly, 13: 139-150.

Knight, D., Pearce, C. L., Smith, K. G., Olian, J. D., Sims, H. P., Smith, K. A., \& Flood, P. 1999. Top management team diversity, group process, and strategic consensus. Strategic Management Journal, 20: 445-465.

Korsgaard, M. A., Schweiger, D. M., \& Sapienza, H. J. 1995. Building commitment, attachment, and trust in strategic decision-making teams: The role of procedural justice. Academy of Management Journal, 38: 60-84.

Kotter, J. P. 1995. Leading change: Why transformation efforts fail. Harvard Business Review, 73: 59-67.

Labianca, G., Gray, B., \& Brass, D. J. 2000. A grounded model of organizational schema change during empowerment. Organization Science, 11: 235-257.

Larwood, L., Falbe, C. M., Kriger, M. P., \& Miesing, P. 1995. Structure and meaning of organizational vision. Academy of Management Journal, 38: 740-769.

Leana, C. R., \& Van Buren, H. J. 1999. Organizational social capital and employment practices. Academy of Management Review, 24: 538-555.

Lee, E., \& Puranam, P. 2016. The implementation imperative: Why one should implement even imperfect strategies perfectly. Strategic Management Journal, 37: 1529-1546.

Mael, F., \& Ashforth, B. E. 1992. Alumni and their alma mater: A partial test of the reformulated model of organizational identification. Journal of Organizational Behavior, 13: 103-123.

Markoczy, L. 2001. Consensus formation during strategic change. Strategic Management Journal, 22: 1013-1031.

Martocchio, J. J., \& Frink, D. D. 1994. A review of the influence of group goals on group performance. Academy of Management Journal, 37: 1285-1301.

Mathieu, J. E., Heffner, T. S., Goodwin, G. F., Salas, E., \& Cannon-Bowers, J. A. 2000. The influence of shared mental models on team process and performance. Journal of Applied Psychology, 85: 273-283.

Mathieu, J., Maynard, M. T., Rapp, T., \& Gilson, L. 2008. Team effectiveness 1997-2007: A review of recent advancements and a glimpse into the future. Journal of Management, 34: 410-476.

McClelland, G. H., \& Judd, C. M. 1993. Statistical difficulties of detecting interactions and moderator effects. Psychological Bulletin, 114: 376-390.

Meyer, C. B. 2006. Destructive dynamics of middle management intervention in postmerger processes. The Journal of Applied Behavioral Science, 42: 397-419.

Mintzberg, H., \& Waters, J. A. 1985. Of strategies, deliberate and emergent. Strategic Management Journal, 6: 257-272.

Muller, D., Judd, C. M., \& Yzerbyt, V. Y. 2005. When moderation is mediated and mediation is moderated. Journal of Personality and Social Psychology, 89: 852-863.

Noble, C. H. 1999. The eclectic roots of strategy implementation research. Journal of Business Research, 45 : 119-134.

Oreg, S. 2003. Resistance to change: Developing an individual differences measure. Journal of Applied Psychology, 88: 680-693. 
O’Reilly, C. A., Caldwell, D. F., Chatman, J. A., Lapiz, M., \& Self, W. 2010. How leadership matters: The effects of leaders' alignment on strategy implementation. Leadership Quarterly, 21: 104-113.

Parayitam, S., \& Dooley, R. S. 2011. Is too much cognitive conflict in strategic decision-making teams too bad? International Journal of Conflict Management, 22: 342-357.

Podsakoff, P. M., MacKenzie, S. B., Lee, J. Y., \& Podsakoff, N. P. 2003. Common method biases in behavioral research: A critical review of the literature and recommended remedies. Journal of Applied Psychology, 88: 879-903.

Podsakoff, P. M., MacKenzie, S. B., \& Podsakoff, N. P. 2012. Sources of method bias in social science research and recommendations on how to control it. Annual Review of Psychology, 63: 539-569.

Porck, J. P., van Knippenberg, D., Tarakci, M., Ates, N. Y., Groenen, P. J. F., \& de Haas, M. 2018. Do group and organizational identification help or hurt intergroup strategic consensus? Journal of Management. Advance online publication. doi:10.1177/0149206318788434

Powell, T. C., Lovallo, D., \& Fox, C. R. 2011. Behavioral strategy. Strategic Management Journal, 32: 1369-1386.

Preacher, K. J., Rucker, D. D., \& Hayes, A. F. 2007. Addressing moderated mediation hypotheses: Theory, methods, and prescriptions. Multivariate Behavioral Research, 42: 185-227.

Priem, R. L. 1990. Top management team group factors, consensus, and firm performance. Strategic Management Journal, 11: 469-478.

Raes, A. M. L., Heijltjes, M. G., Glunk, U., \& Roe, R. A. 2011. The interface of the top management team and middle managers: A process model. Academy of Management Review, 36: 102-126.

Rafferty, A. E., \& Griffin, M. A. 2004. Dimensions of transformational leadership: Conceptual and empirical extensions. Leadership Quarterly, 15: 329-354.

Rouleau, L., \& Balogun, J. 2011. Middle managers, strategic sensemaking, and discursive competence. Journal of Management Studies, 48: 953-983.

Samba, C., Van Knippenberg, D., \& Miller, C. C. 2018. The impact of strategic dissent on organizational outcomes: A meta-analytic integration. Strategic Management Journal, 39: 379-402.

Sashkin, M. 1988. The visionary leader. In J. A. Conger \& R. N. Kanugo (Eds.), Charismatic leadership: 120-160. San Francisco: Jossey-Bass.

Semadeni, M., Withers, M. C., \& Trevis Certo, S. 2014. The perils of endogeneity and instrumental variables in strategy research: Understanding through simulations. Strategic Management Journal, 35: 1070-1079.

Shamir, B., \& Howell, J. M. 1999. Organizational and contextual influences on the emergence and effectiveness of charismatic leadership. Leadership Quarterly, 10: 257-283.

Sharma, G., \& Good, D. 2013. The work of middle managers: Sensemaking and sensegiving for creating positive social change. Journal of Applied Behavioral Science, 49: 95-122.

Shipley, R., \& Michela, J. L. 2006. Can vision motivate planning action? Planning, Practice \& Research, 21: 223244.

Sillince, J., \& Mueller, F. 2007. Switching strategic perspective: The reframing of accounts of responsibility. Organization Studies, 28: 155-176.

Stam, D., Lord, R. G., van Knippenberg, D., \& Wisse, B. 2014. An image of who we might become: Vision communication, possible selves, and vision pursuit. Organization Science, 25: 1172-1194.

Stam, D., van Knippenberg, D., \& Wisse, B. 2010. Focusing on followers: The role of regulatory focus and possible selves in visionary leadership. Leadership Quarterly, 21: 457-468.

Tarakci, M., Ateş, N. Y., Floyd, S. W., Ahn, Y., \& Wooldridge, B. 2018. Performance feedback and middle managers' divergent strategic behavior: The roles of social comparisons and organizational identification. Strategic Management Journal, 39: 1139-1162.

Tarakci, M., Ates, N. Y., Porck, J. P., van Knippenberg, D., Groenen, P. J., \& de Haas, M. 2014. Strategic consensus mapping: A new method for testing and visualizing strategic consensus within and between teams. Strategic Management Journal, 35: 1053-1069.

van Knippenberg, D., \& Schippers, M. C. 2007. Work group diversity. Annual Review of Psychology, 58: 515-541.

van Knippenberg, D., \& Sitkin, S. B. 2013. A critical assessment of charismatic-transformational leadership research: Back to the drawing board? Academy of Management Annals, 7: 1-60.

van Knippenberg, D., \& Stam, D. 2014. Visionary leadership. In D. V. Day (Ed.), The Oxford handbook of leadership and organizations: 241-259. New York: Oxford University Press.

van Knippenberg, D., van Ginkel, W. P., \& Homan, A. C. 2013. Diversity mindsets and the performance of diverse teams. Organizational Behavior and Human Decision Processes, 121: 183-193. 
Venus, M., Stam, D., \& van Knippenberg, D. 2013. Leader emotion as a catalyst of effective leader communication of visions, value-laden messages, and goals. Organizational Behavior and Human Decision Processes, 122: 53-68.

Venus, M., Stam, D., \& van Knippenberg, D. 2018. Visions of change as visions of continuity. Academy of Management Journal. Advance online publication. doi:10.5465/amj.2015.1196

Walsh, J. P. 1995. Managerial and organizational cognition: Notes from a trip down memory lane. Organization Science, 6: 280-321.

Walter, J., Kellermanns, F. W., Floyd, S. W., Veiga, J. F., \& Matherne, C. 2013. Strategic alignment: A missing link in the relationship between strategic consensus and organizational performance. Strategic Organization, 11: 304-328.

Westley, F., \& Mintzberg, H. 1989. Visionary leadership and strategic management. Strategic Management Journal, 10: $17-32$.

Wooldridge, B., \& Floyd, S. W. 1989. Strategic process effects on consensus. Strategic Management Journal, 10: 295-302.

Wooldridge, B., \& Floyd, S. W. 1990. The strategy process, middle management involvement, and organizational performance. Strategic Management Journal, 11: 231-241.

Wooldridge, B., Schmid, T., \& Floyd, S. W. 2008. The middle management perspective on strategy process: Contributions, synthesis, and future research. Journal of Management, 34: 1190-1221.

Yin, R. K. 2013. Case study research: Design and methods. Thousand Oaks, CA: SAGE.

Yukl, G. 2012. Effective leadership behavior: What we know and what questions need more attention. Academy of Management Perspectives, 26: 66-85. 